\section{ARCHIMEDES AND MEDIEVAL SCIENCE}

Archimedes in the Middle Ages

By Marshall Clagett. Vol. 1: The Arabo-Latin Tradition. Pp. xxix + 720. (Madison: University of Wisconsin Press, 1964.) 12 dollars.

$\mathrm{I}^{\mathrm{T}}$

$T$ is undoubtod that the discoveries of Archimedes, I"the greatest mathematician of antiquity whose fundamental work affects every branch of science", had a most important influence on medieval science and its exponents. For example, Galileo praised and quoted him frequently, as did Leonardo da Vinci. In this scholarly volume Prof. M. Clagett, by sedulous care, study and exhaustive research pursued over many years in the libraries of Europe, has assembled seventeen texts in Latin, all medieval versions of the works of Archimedes and his followers. They include previously unpublished texts discovered by Prof. Clagett, or new versions of earlier attempts based on more intensive study, or wider collation of manuscripts. All the texts are translated into English for the first time, the translation and the original Latin version being printed on facing pages. The book, therefore, substantiates its additional claim to rank as a standard source of reference for scholars of the period who are interested in textual problems. These Archimedean texts, first translated by learned Arabs from Greek into Arabic, were in turn translated from Arabic into Latin by medieval scholars, for example, Plato of Tivoli (probably) and Gerard of Cremona. To this statement Prof. Clagett makes one exception. He considers that the Latin fragment, Liber de curvis superficiebus, by one Johannes de Tinemue, a mathematician, which spread knowledge of Archimedes's De sphaera et cylindro in the Latin West before 1269, was translated from the Greek, although it has been included with the translations from the Arabic, as is explained in Chapter 6.

Prof. Clagett in an introductory chaptor to his book considers the impact of Archimedes on medieval science; then come the two translations of the De mensura circuli, and six emended versions. Next the Verba filiorum of the Banū Mūsã; this was composed by the celebrated Arabic mathematicians of the ninth contury, the Banū Mūsã ibn Shäkir, three brothers who contributed greatly to Islamic mathematics. Additional versions of the De mensura circuli follow, while tho next chapter surveys various texts and fragments based on Archimedes's De sphaera et cylindro. The final chapter considers the Arabo-Latin tradition of Archimedes in retrospect. Six appendixes are devoted to additional medieval citations and a commentary on Archimodean mathematics. Hore the author points out that medieval mathematicians had a somewhat elementary knowledgo of geometry basod on Euclid's Elements. They were, thereforc, constrained to paraphrase and elaborate the terse and more mature mathematios of Archimedes. Furthormore, the Arabo-Latin translations arc impcrfoct in so far as they make available only a portion of the corpus of Archimedes. Probably this was because only limitod Byzantine Greek texts were available to Arabic scholars.

In 1269 the Flemish Dominican, William of Moerbeke, translated most of the corpus of Archimedes from the Greek text. His translation, the complete version of which exists in only one codex, a Vatican manuscript, included all the texts now known, with the exception of the Sandreckoner, the On the Method, the fragmentary Stomachion and the brief Bovine Problem. It also included two of the three known commontaries of Eutocius, only the commentary on the Measurement of the Circle being missing. In a second volume Prof. Clagett will consider the Monrboke translation and the use made of it by medieval mathematicians. He observes, however, in this first volume that more use continued to be made of the more elementary and incomplete Arabo-Latin works than of the Moerbeke translation.

Finally, it may be noted that although some of the writings of Archimedes have been lost, our knowledge of his work is more complete than that of the medieval schoolmen; for, like other Greek men of science, in the solutions of his problems he gave the final results and his proofs, but did not explain how he arrived at them. It was known that Archimedes had written a treatise On Method, but the manuscript appeared to be irretrievably lost for centuries. Then in 1906 Heiberg found in a library at Constantinople a manuscript prayer book of tho twelfth contury writton on parchment which had been previously used. The original writing had been erased. Heiberg deciphered the palimpsest and found it to be the long-lost treatise On Method. It revealed how Archimedes in his work applied integration and the experimental use of mechanies as a preliminary to mathematical demonstration, and was dedicated to his friend and fellow scientist Eratosthenes, the erudite librarian of Alexandria, whom he had first known during his visit to Egypt. Indeed, it was at the request of Eratosthenes that Archimedes explained his method of procedure and thereby benefited posterity.

Prof. Clagett's book will be appreciated and valued not only by physicists and mathematicians but by all readers who are interested in the history of science. We look forward to his second volume. Akthur MacNaxty

\section{PERTURBATION METHODS IN FLUID MECHANICS}

\section{Perturbation Methods in Fluid Mechanics}

By Milton Van Dyke. (Applied Mathematics and Mechanics : an International Series of Monographs, Vol. 8.) Pp. $x+229$. (Now York: Academic Press, Inc.; London: Academic Press, Inc. (London), Ltd., 1964.) 56s.

7 HIS well-written book desorves, and will I havo no doubt get, an appreciative reception. Perturbation mothods have long beon in use as a means of dealing with the non-linear equations which arise in many physical problems, and fluid mechanics is no exception in this respect. Some problems can be solvod by straightforward techniques involving expansions by successive approximation in terms of a parameter which is physically small. In many other problems such techniques, in their most elementary form, break down because the expansion so obtained is not uniformly valid. Brondly spenking, this difficulty arises from the occurrence of a singularity. The first approximation, in an attempted successive approximation approach, usually brings out the existence of a singularity, but the second approximation then produces a singularity of higher order and so on, the expansion becoming more and more singular as ono proceeds. Such a straightforward technique leads to a series which has zero radius of convergence at the singular point of the first approximation. This approach fails because the first approximation displaces the singularity from its correct position and, to quote Van Dyke, "in the higher order approximations it is spuriously intensified rather than being corrected".

Two main methods have been developed for dealing with such singular perturbation problems. The first is associated with the names of Lighthill and Whitham (and earlior with Jeffreys and Poinoaré). The socond was introduced by Prandtl, who was followed by Friedrichs and then by Lagorstrom, Kaplun, Cole and Van Dyke, who colloctively have formalized it. In this book the author refers to the former as the method of strained co-ordinates and to the latter as the method of matched asymptotic expansions. 